\title{
Early pair housing increases solid feed intake and weight gains in dairy calves
}

\author{
J. H. C. Costa, R. K. Meagher, M. A. G. von Keyserlingk, and D. M. Weary ${ }^{1}$ \\ Animal Welfare Program, Faculty of Land and Food Systems, University of British Columbia, Vancouver, BC, Canada V6T $1 Z 4$
}

\section{ABSTRACT}

Dairy calves have traditionally been kept in individual pens throughout the milk-feeding period. Social rearing is associated with increased solid feed intake and, hence, higher weight gains before and after weaning. Little is known about the effect of the age at which social housing begins. The aim of this study was to assess the effects of early versus late pairing on feeding behavior and weight gain before and after weaning. Holstein bull calves were reared individually $(\mathrm{n}=8$ calves) or paired with another calf at $6 \pm 3 \mathrm{~d}(\mathrm{n}=8$ pairs) or $43 \pm 3 \mathrm{~d}$ of age ( $\mathrm{n}=8$ pairs). All calves were fed $8 \mathrm{~L}$ of milk/d for $4 \mathrm{wk}, 6 \mathrm{~L} / \mathrm{d}$ from 4 to $7 \mathrm{wk}$, and then milk was reduced by $20 \% / \mathrm{d}$ until calves were completely weaned at 8 wk of age. Calves were provided ad libitum access to calf starter and a total mixed ration (TMR). Body weight and feed intake were measured weekly from 3 to $10 \mathrm{wk}$ of age. Intake of calf starter was significantly higher for the early-paired calves than for individually reared and late-paired calves throughout the experimental period. At $10 \mathrm{wk}$ of age, starter dry matter intake averaged $2.20 \pm 0.22,1.09 \pm 0.25$, and $1.26 \pm 0.33 \mathrm{~kg} / \mathrm{d}$ for early-paired, late-paired, and individually housed calves, respectively. Intake of TMR did not differ among treatments, TMR dry matter intake averaged $3.27 \pm 0.72,3.08 \pm 0.46$, and $2.89 \pm 0.54 \mathrm{~kg} / \mathrm{d}$ for the same 3 treatments. Calves in the early paired treatment also showed significantly higher average daily gain over the experimental period $(0.89 \pm 0.04 \mathrm{vs}$. $0.76 \pm 0.04$ and $0.73 \pm 0.04 \mathrm{~kg} / \mathrm{d}$ for the early-paired, individual, and late-paired calves, respectively). These results indicate that social housing soon after birth can increase weight gains and intake of solid feed.

Key words: weaning, animal welfare, social facilitation, social learning, Holstein

Received January 29, 2015.

Accepted May 31, 2015.

${ }^{1}$ Corresponding author: danweary@mail.ubc.ca

\section{INTRODUCTION}

Dairy farms often separate calves from their dams within $24 \mathrm{~h}$ after birth and then house calves individually (USDA, 2008; Vasseur et al., 2010; Hötzel et al., 2014). Housing milk-fed calves in pairs or groups is increasing in popularity, in part due to the potential of reducing labor requirements per head. Social housing can also provide animal welfare benefits, as it allows calves to perform social behaviors and can provide calves more useable space (Jensen et al., 1997; Færevik et al., 2006).

Calves that consume little solid feed before weaning are more likely to experience poor growth and prolonged hunger after weaning until intake of solid feed meets their requirements for maintenance and growth (Jasper and Weary, 2002; de Passillé et al., 2011). Encouraging solid intakes early in life can help smooth the transition from milk to solid feed at weaning. Social housing of dairy calves has been shown to reduce behavioral responses to weaning and improve performance when mixed with a larger group after weaning (de Paula Vieira et al., 2012). Housing dairy calves in a social group also reduces food neophobia (Costa et al., 2014). Group-housed calves have increased weaning weights compared with individually housed calves, likely due to increased DMI during the preweaning period (Chua et al., 2002; Xiccato et al., 2002; de Paula Vieira et al., 2010; Bernal-Rigoli et al., 2012). Increased DMI is often attributed to social learning and social facilitation during feeding (Launchbaugh and Howery, 2005).

On some farms calves are housed individually for the first weeks of life and then paired or moved to a group around the time of weaning (Staněk et al., 2014), but it is unknown when contact with peers is necessary to achieve the benefit of increased early intake of solids. The aim of the current study was to assess the effects of early and late pairing on feeding behavior and weight gain before and after weaning. We predicted that calves paired early in life (at $6 \mathrm{~d}$ ) would begin eating solids at a younger age, consume more solids throughout the preweaning period, and gain more $\mathrm{BW}$ in comparison with calves housed individually or calves paired later in life (6 wk of age). 


\section{MATERIALS AND METHODS}

This experiment was carried out between April and December of 2013 at the University of British Columbia's Dairy Education and Research Centre, located in Agassiz, British Columbia, Canada $\left(49^{\circ} \mathrm{N}, 121^{\circ} \mathrm{W}\right)$. All procedures carried out in the current study were approved by the University of British Columbia Animal Ethics Committee (AUP A12-0337).

\section{General Methodology and Treatments}

Forty Holstein bull calves were enrolled at birth. Calves were separated from their dam and fed at least 4 $\mathrm{L}$ of colostrum (with $>50 \mathrm{~g} / \mathrm{L}$ of $\mathrm{IgG}$ ) by bottle within $6 \mathrm{~h}$ of birth. Blood samples were collected from the jugular vein $24 \mathrm{~h}$ after the first feeding of colostrum and serum was analyzed using a Reichert AR 200 Digital Hand-Held Refractometer (Reichert, Depew, NY). Only calves with serum protein $>5.5 \mathrm{~g} / \mathrm{dL}$ were kept in the trial. After birth, calves were weighed (mean $=43.5$ $\pm 5.1 \mathrm{~kg}$ of BW) and moved to individual pens with no visual contact with any other calf and were bottle-fed up to $8 \mathrm{~L}$ of whole milk daily.

At $6 \pm 3$ d of age calves were assigned to 1 of 3 treatments: individual $(\mathrm{n}=8)$, early pairing $(\mathrm{n}=8$ pairs $)$, or late pairing ( $\mathrm{n}=8$ pair). Assignment was random within blocks of 5 calves, within the constraint that calves closest in age were assigned to pair treatments. Individually reared calves were kept in individual pens $(1.2 \times 2 \mathrm{~m})$ on sawdust bedding, with no visual contact with any other calf for the entire length of the experiment $(70 \mathrm{~d})$. For early-paired calves, 2 calves were paired at $6 \pm 3 \mathrm{~d}$ of age by having the barrier to the neighboring pen removed to create a double pen. For late-paired calves, the individual housing continued until the age of $43 \pm 3 \mathrm{~d}, 14 \mathrm{~d}$ before weaning. In both pair-housing treatments, calves were provided twice the area $(2.4 \times 2.0 \mathrm{~m})$, milk bottle holders, and water and solid feed buckets in the same pen system as the individually raised calves.

\section{Milk Delivery, Solid Feeding, and Weaning}

All calves were bottle-fed pasteurized whole milk twice per day. From 0 to 28 d of age, calves in all treatments received $8 \mathrm{~L} / \mathrm{d}$ of whole pasteurized milk, divided in 2 feedings, delivered at 0800 and $1630 \mathrm{~h}$. From d 29 to 49 calves were fed $6 \mathrm{~L} / \mathrm{d}$, fed as described above. From d 50 to 54 , milk was reduced by $20 \%$ /d for $5 \mathrm{~d}$ until calves were completely weaned at d 55 . Calves were enrolled in the experiment until d 70. All calves had ad libitum access to water, TMR (shown as percent of DM, consisting of $26.1 \%$ corn silage, $14.8 \%$ grass si- lage, $10 \%$ alfalfa hay, and $49 \%$ concentrated mix; which was on average $49.1 \pm 1.5 \% \mathrm{DM}$; chemical composition shown as percent of DM, CP $17 \%$, NDF $32 \%, \mathrm{ADF}$ $20 \%$ ) and calf starter [Hi-Pro Medicated Calf Starter, Chilliwack, BC, Canada, with an overall DM of 89.5\%; chemical composition shown as percent of DM, $90 \%$ DM; CP 21\%, NDF 19\%, ADF 11\%; medicated with a coccidiostat (50 mg/kg of lasalocid sodium)] during the experimental period. Samples of the feed were taken before feeding once every other week and frozen; at the end of the experiment the samples were sent to A\&L Canada Laboratories Inc. (London, ON, Canada). Samples for nutrient and DM analysis were oven-dried at $55^{\circ} \mathrm{C}$ for $48 \mathrm{~h}$. Dried samples were ground to pass through a 1-mm screen and for analysis of ADF (AOAC International, 2000: method 973.18), NDF with heatstable $\alpha$-amylase and sodium sulfite (Van Soest et al., 1991), and $\mathrm{CP}(\mathrm{N} \times 6.25$; AOAC International 2000: method 990.03; Leco FP-528 Nitrogen Analyzer, Leco, St. Joseph, MI). Fresh feed and water were delivered daily at approximately $0830 \mathrm{~h}$ and feed refusals were removed before the new feed was delivered. Daily (24 h) calf starter and TMR intakes were determined each morning by disappearance.

\section{Performance and Health}

Calves were weighed and health-scored weekly. Individual BW of each calf was recorded and ADG was calculated for the preweaning period ( 3 to $6 \mathrm{wk}$ ), the weaning period (6 to $10 \mathrm{wk}$ ), and over the whole experimental period (3 to $10 \mathrm{wk}$ ). Health checks were performed following de Paula Vieira et al. (2010), which consisted of diarrhea scoring, where $1=$ normal feces; 2 = plaques but not watery; $3=$ watery and body temperature $<39.5^{\circ} \mathrm{C}$; and $4=$ watery and body temperature $\geq 39.5^{\circ} \mathrm{C}$. Calves with a score of 4 were treated with electrolytic solutions (Hydrafeed, EXL Laboratories, Minneapolis, MN), and calves failing to respond to treatment within $2 \mathrm{~d}$ were administered a nonsteroidal ant-inflammatory drug (NSAID; Metacam $20 \mathrm{mg} / \mathrm{mL}$, Boehringer Ingelheim, Burlington, ON, Canada), according to our farm's standard procedure. During the experimental period, 3 calves from the early-paired, 3 calves from the late-paired, and 1 calf from the individually reared treatment were treated with NSAID. Clinical examination of respiratory health was also performed. Calves showing nasal discharge and pathological sounds of pulmonary infection during auscultation were classified as ill and treated with antibiotic drugs (Resflor GOLD, Intervet Inc., Roseland, NJ) according to the farm's standard operating procedure. During the experimental period, 2 calves from each treatment were treated with antibiotic drugs. 


\section{Statistical Analysis}

All analyses were performed with SAS (version 9.4; SAS Institute Inc., Cary, NC) using the pen (i.e., calf or pair) as the experimental unit. Intake of TMR and calf starter were measured daily but averaged to form weekly values for intake per calf per day. Intake of TMR and calf starter are expressed on a DM basis. Dry matter intake of TMR and calf starter, total DMI (i.e., $\mathrm{TMR}+$ calf starter), ADG, and birth BW were considered as dependent variables. Prior to analysis, data were checked for normality using the UNIVARIATE procedure in SAS and probability distribution plots. The effect of treatment on each variable was tested using the MIXED procedure in SAS.

For the variables intake of TMR, calf starter and total DMI the model included treatment, week, and the interaction of the week and the treatments. Week was specified as a repeated measure and calf or pair specified as subject, using an autoregressive covariance structure. Average daily gain over each period (preweaning, weaning, and over the whole experimental period) was calculated and tested in a model that included treatment and calf or pair as a random effect. The PDIFF statement was used to compare the least squares means of each combination of treatments, and the $P$-values were corrected using the Bonferroni correction.

\section{RESULTS}

Intake of TMR was similar across the 3 treatments $\left(\mathrm{F}_{2,22}=0.46 ; P=0.63 ;\right.$ Figure 1a), but early-paired calves ate more calf starter $\left(\mathrm{F}_{2,22}=3.46 ; P=0.03\right.$; Figure 1b) and consequently showed higher total DMI $\left(\mathrm{F}_{2,22}=10.61 ; P<0.001 ;\right.$ Figure $\left.1 \mathrm{c}\right)$ relative to the individual and late-paired treatments. Solid feed intake was minimal until calves were 3 wk old. At 6 wk, intake of TMR was not different between treatments $\left(\mathrm{F}_{2,22}\right.$ $=1.40 ; P=0.27)$ and averaged $0.17 \pm 0.07,0.31 \pm$ $0.07,0.18 \pm 0.06 \mathrm{~kg} / \mathrm{d}$, for individual, early-paired, and late-paired calves, respectively. Starter intake was similar for the individually reared and late-paired calves $(0.07 \pm 0.03$ and $0.05 \pm 0.03 \mathrm{~kg} / \mathrm{d})$ but higher for the early-paired calves $\left(0.18 \pm 0.03 \mathrm{~kg} / \mathrm{d} ; \mathrm{F}_{2,22}=5.00 ; P\right.$ $=0.02)$. Consumption increased after weaning in all treatments, but this increase was greatest for the earlypaired calves. At $10 \mathrm{wk}$ of age, intake of calf starter was higher than the other 2 treatments $\left(\mathrm{F}_{2,22}=4.11 ; P=\right.$ $0.03)$. Calf starter intake averaged $2.20 \pm 0.22,1.09 \pm$ 0.25 , and $1.26 \pm 0.33 \mathrm{~kg} / \mathrm{d}$ for early-paired, late-paired, and individual calves, respectively. Intake of TMR did not differ among treatments $\left(\mathrm{F}_{2,22}=1.18 ; P=0.33\right)$; TMR intake averaged $3.27 \pm 0.72,3.08 \pm 0.46$, and $2.89 \pm 0.54 \mathrm{~kg} / \mathrm{d}$ for the same 3 treatments.
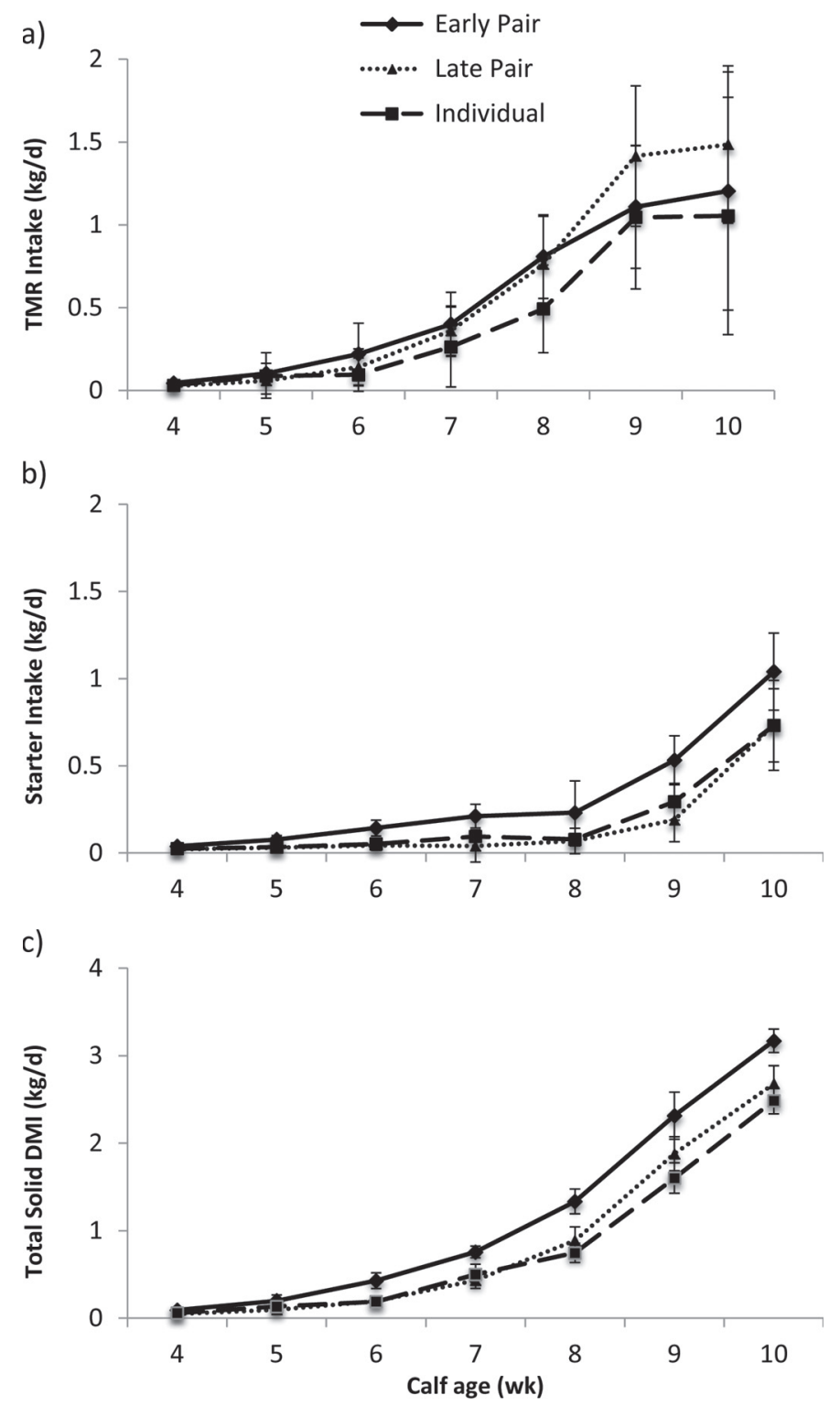

Figure 1. Least squares means $( \pm \mathrm{SE})$ of a) TMR ( $\mathrm{kg}$ of DM), (b) calf starter ( $\mathrm{kg}$ of DM), and (c) solid feed DMI ( $\mathrm{kg}$ of DM) for earlypaired (paired at $6 \pm 3 \mathrm{~d}$ of age; $\mathrm{n}=8$ pairs), late-paired (paired at $43 \pm 3 \mathrm{~d}$ of age; $\mathrm{n}=8$ pairs) and individual calves ( $\mathrm{n}=8$ calves). Weekly averages are shown in relation to calf age, with age ranging from 4 to $10 \mathrm{wk}$.

Calves in the early-paired treatment gained more weight than did the calves in the other 2 treatments during the entire experimental period $(0.89 \pm 0.04$ vs. $0.76 \pm 0.04$ and $0.73 \pm 0.04 \mathrm{~kg} / \mathrm{d}$ for the early-paired, individual, and late-paired calves, respectively; $\mathrm{F}_{2,22}=$ 4.87; $P<0.01)$. Average daily gain was not different between treatments during the preweaning period (3 to 6 wk; $F_{2,22}=0.98 ; P=0.39$; Figure $\left.2 \mathrm{a}\right)$, but earlypaired calves had higher ADG $\left(\mathrm{F}_{2,22}=4.13 ; P=0.03\right.$; 
Figure $2 \mathrm{~b}$ ) during the weaning period (6 to $10 \mathrm{wk}$ ) relative to the individual and late pair treatments.

\section{DISCUSSION}

This study is the first to explore the effects on feed intake of late pairing of calves, in comparison to early pair housing and individual housing. Early pair housing increased calf feed intake and BW. Calves paired soon after birth began to consume solid feed earlier than late-paired and individually housed calves, likely contributing to the increased weight gains.

The findings of the current study, showing increased intake by socially housed calves, are consistent with earlier work on social versus individual housing (Chua et al., 2002; Xiccato et al., 2002; de Paula Vieira et al., 2010; Bernal-Rigoli et al., 2012). The results of the current study indicate that grouping must occur before 6 wk to provide this benefit. Tapki (2007) compared calves grouped at birth versus at 3 wk of age and found no difference in solid feed intake.

The results of the current study are also consistent with previous work showing that early grouping can have an important influence on the development of dairy calves. For example, social housing is associated with cognitive benefits including improved performance in reversal learning and improved object recognition (Gaillard et al., 2014). Duve and Jensen (2012) found that when calves were housed individually for $3 \mathrm{wk}$ and then paired they performed more social behaviors than calves housed individually with limited social contact throughout the preweaning period. Only minor differences were found between calves housed together from birth compared with those paired at 3 wk of life. In combination, these results indicate that the critical phase for grouping occurs sometime between 3 and 6 wk of age, as calves paired at 3 wk did not differ from calves paired at birth. Based upon these results our conservative recommendation is to group calves within the first $3 \mathrm{wk}$ of life.

The early-paired calves in the current study gained weight at a faster rate than did the individually reared and late-paired calves. This increased ADG can be explained by the greater solid feed intake. Solid feed intakes are likely to be an important determinant of gains, especially when calves are fed limited quantities of milk (see review by Khan et al., 2011). Solid intakes likely became more important to growth in the current study after 4 wk of age, when the milk ration was reduced from 8 to 6 L. An additional benefit of establishing high solid intakes before weaning is that calves should then transition more smoothly to exclusively solid feed when milk is fully withdrawn at weaning. Although all treatment groups exhibited a growth check during
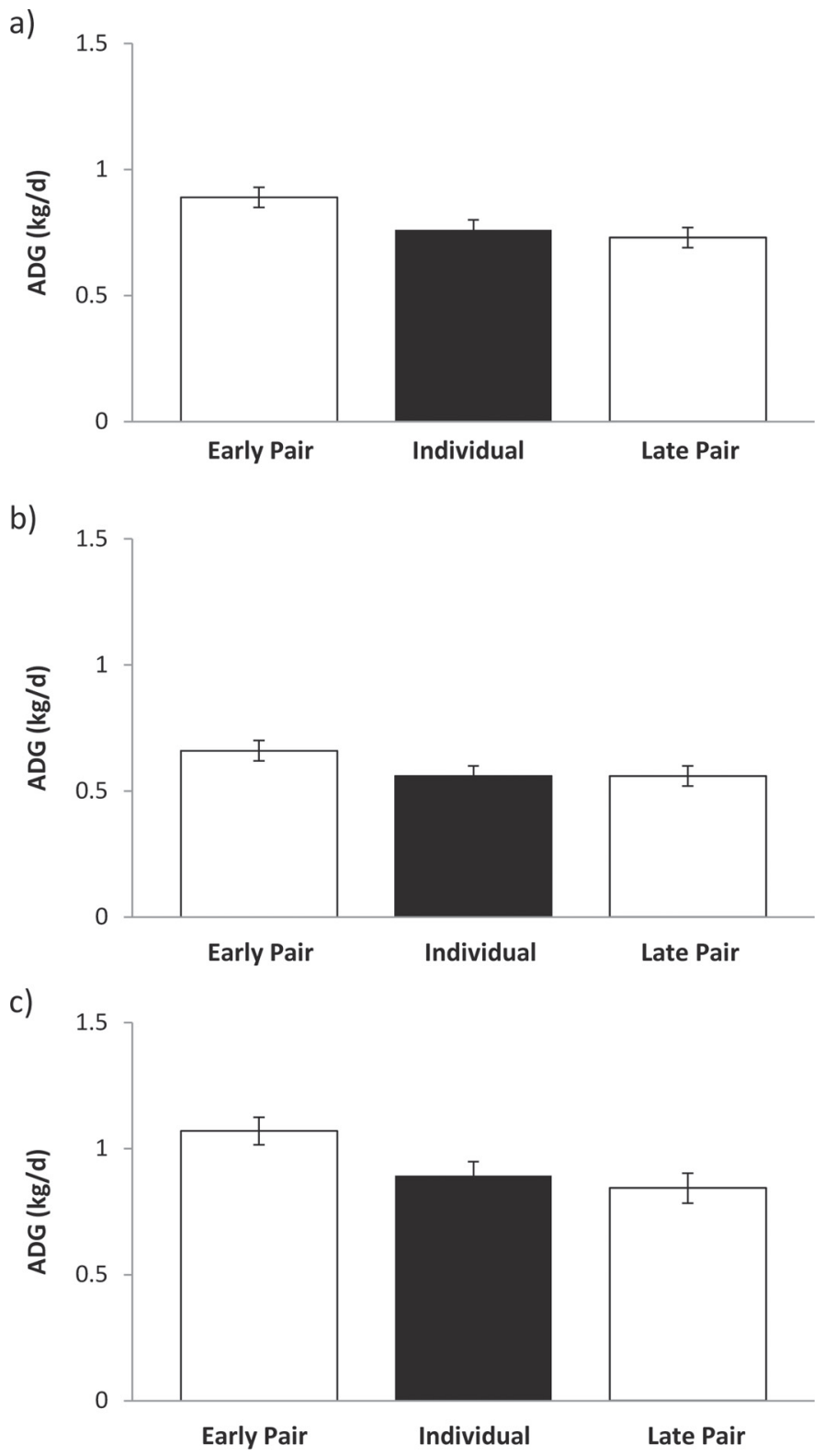

Figure 2. Least squares means $( \pm \mathrm{SE}) \mathrm{ADG}(\mathrm{kg} / \mathrm{d})$ for early-paired (paired at $6 \pm 3$ d of age; $\mathrm{n}=8$ pairs), late-paired (paired at $43 \pm 3$ d of age; $n=8$ pairs), and individually housed calves ( $\mathrm{n}=8$ calves) during (a) the entire experimental period (wk 3 to 10) and separately from (b) the preweaning period (wk 3 to 6 ) and (c) the weaning period (wk 6 to 10).

weaning at wk 7 , this check was more pronounced in individually raised calves than in late- and early-paired calves, indicating an advantage to being paired during the weaning phase. A reduced growth check at weaning for group-housed calves has also been reported in earlier studies (Chua et al., 2002; de Paula Vieira et al., 2010). In addition to potential animal welfare benefits from the higher gains, this early advantage in BW is likely to benefit farm profitability; recent research has 
shown the advantages of higher weight gains in calves on the onset of puberty and first lactation, as well as overall milk production (Moallem et al., 2010; Soberon et al., 2012).

A recent paper found that social contact was associated with increased solid feed intake when calves were fed a high intake of milk, but not when calves were fed low milk volumes (Jensen et al., 2015). Feeding low volumes of milk increases calf hunger (de Paula Vieira et al., 2008), increasing motivation to eat solid feed. Thus, the effects of social housing on solid intakes are expected to be greatest for calves with higher milk intakes, as in the current study.

In the current study TMR intake did not differ among treatments. This result contrasts with that of Phillips (2004), in which calves reared in groups showed increased intakes of grass (but not starter) relative to calves housed individually. The difference between these 2 studies may be due to differences in motivation to consume solid feed. In the current study, calves were fed $8 \mathrm{~L} / \mathrm{d}$ and in the study by Phillips (2004) calves received $4 \mathrm{~L} / \mathrm{d}$. Increased milk allowance is thought to increase motivation to consume forages (as reviewed by Khan et al., 2011), and all calves in our study consumed high quantities of TMR. Intakes were more variable for calf starter, likely making it easier to detect the beneficial effects of social rearing on calf starter intake. In contrast, Phillips (2004) fed calves just $4 \mathrm{~L}$ of milk/d, likely leaving animals highly motivated to eat concentrate. In this context, intakes of concentrates were likely consistently high, such that treatment differences were more likely to be observed for forage intake.

The increased intake of solids may be due to social facilitation, social learning, or some combination. Social facilitation can be defined as "the initiation of a particular response while observing others engaged in that behavior" (Galef, 1988); in this way the stimulus of an animal eating or approaching the feed would increase the likelihood of the other calf in the same pen performing the same behaviors. Social learning can be defined as learning that is influenced by observation of, or interaction with, another individual (Keeling and Hurnik, 1996). In the previous literature on the development of feeding behavior in farmed species some authors have implicated social facilitation (e.g., Ralphs et al., 1994) and other social learning (e.g., Launchbaugh and Howery, 2005), but in our view distinguishing between these mechanisms is not possible based on the current data and should be explored in future work. Also, if socially reared calves eat more solids simply because their attention is drawn to the feed by their social partner, other methods that draw attention to the feed may also be effective at increasing early intakes. For example, mechanically shaking or changing the feed might also increase attention and ultimately increase intakes. In piglets, it has been shown that a play feeder (an open trough with 3 protrusions to stimulate exploration) can increase creep feed intake (Kuller et al., 2010). To our knowledge this approach has never been applied to dairy calves.

In conclusion, dairy calves benefit from early social housing in terms of increased solid intakes and increased gains. To achieve these benefits calves should be grouped within 3 wk of life.

\section{ACKNOWLEDGMENTS}

We thank the staff and students of the University of British Columbia (UBC) Dairy Education and Research Centre who helped in this experiment, especially Eraldo Drago Filho, Venessa Wong, and Alan Makarewicz for their help with data collection. Joao H.C. Costa is supported by CNPq (The Brazilian National Council for Scientific and Technological Development, Brasilia, Brazil). This research was funded by a Discovery Grant to D. M. Weary from Canada's Natural Sciences and Engineering Research Council (NSERC, Ottawa, Canada). General funding for UBC's Animal Welfare Program comes from an NSERC Industrial Research Chair with industry contributions from the Dairy Farmers of Canada (Ottawa, ON, Canada), British Columbia Dairy Association (Burnaby, BC Canada), Westgen Endowment Fund (Milner, BC, Canada), Intervet Canada Corporation (Kirkland, QC, Canada), Novus International Inc. (Oakville, ON, Canada), Zoetis (Kirkland, QC, Canada), BC Cattle Industry Development Fund (Kamloops, BC, Canada), Alberta Milk (Edmonton, AB, Canada), Valacta (St. Anne-deBellevue, QC, Canada), and CanWest DHI (Guelph, ON, Canada).

\section{REFERENCES}

AOAC International. 2000. Official Methods of Analysis. 17th ed. Vol. 1. AOAC Int., Arlington, VA.

Bernal-Rigoli, J. C., J. D. Allen, J. A. Marchello, S. P. Cuneo, S. R. Garcia, G. Xie, L. W. Hall, C. D. Burrows, and G. C. Duff. 2012. Effects of housing and feeding systems on performance of neonatal Holstein bull calves. J. Anim. Sci. 90:2818-2825.

Chua, B., E. Coenen, J. Van Delen, and D. M. Weary. 2002. Effects of pair versus individual housing on the behavior and performance of dairy calves. J. Dairy Sci. 85:360-364.

Costa, J. H. C., R. R. Daros, M. A. G. von Keyserlingk, and D. M. Weary. 2014. Complex social housing reduces food neophobia in dairy calves. J. Dairy Sci. 97:7804-7810.

de Passillé, A. M., T. F. Borderas, and J. Rushen. 2011. Weaning age of calves fed a high milk allowance by automated feeders: Effects on feed, water, and energy intake, behavioral signs of hunger, and weight gains. J. Dairy Sci. 94:1401-1408.

de Paula Vieira, A., V. Guesdon, A. M. de Passillé, M. A. G. von Keyserlingk, and D. M. Weary. 2008. Behavioural indicators of hunger in dairy calves. Appl. Anim. Behav. Sci. 109:180-189. 
de Paula Vieira, A., M. A. G. von Keyserlingk, and D. M. Weary. 2010. Effects of pair versus single housing on performance and behavior of dairy calves before and after weaning from milk. J. Dairy Sci. 93:3079-3085

de Paula Vieira, A., M. A. G. von Keyserlingk, and D. M. Weary. 2012. Presence of an older weaned companion influences feeding behavior and improves performance of dairy calves before and after weaning from milk. J. Dairy Sci. 95:3218-3224.

Duve, L. R., and M. B. Jensen. 2012. Social behavior of young dairy calves housed with limited or full social contact with a peer. J. Dairy Sci. 95:5936-5945.

Færevik, G., M. B. Jensen, and K. E. Bøe. 2006. Dairy calves social preferences and the significance of a companion animal during separation from the group. Appl. Anim. Behav. Sci. 99:205-221.

Gaillard, C., R. K. Meagher, M. A. G. von Keyserlingk, and D. M Weary. 2014. Social housing improves dairy calves' performance in two cognitive tests. PLoS ONE 9:e90205.

Galef, B. J. 1988. Communication of information concerning distant diets in a social, central-place foraging species: Rattus norvegicus. Pages 119-139 in Social Learning: Psychological and Biological Perspectives. T. R. Zentall and B. G. Galef, Jr., ed. Erlbaum, Hillsdale, N.J.

Hötzel, M. J., C. Longo, L. F. Balcão, C. S. Cardoso, and J. H. C. Costa. 2014. A Survey of management practices that influence performance and welfare of dairy calves reared in southern Brazil. PLoS ONE 9:e114995.

Jasper, J., and D. M. Weary. 2002. Effects of ad libitum milk intake on dairy calves. J. Dairy Sci. 85:3054-3058.

Jensen, M. B., L. R. Duve, and D. M. Weary. 2015. Pair housing and enhanced milk allowance increase play behavior and improve performance in dairy calves. J. Dairy Sci. 98:2568-2575. http:// dx.doi.org/10.3168/jds.2014-8272.

Jensen, M. B., K. S. Vestergaard, C. C. Krohn, and L. Munksgaard. 1997. Effect of single versus group housing and space allowance on responses of calves during open-field tests. Appl. Anim. Behav. Sci. 54:109-121.

Keeling, L. J., and J. F. Hurnik. 1996. Social facilitation and synchronization of eating between familiar and unfamiliar newly weaned piglets. Acta Agric. Scand. A Anim. Sci. 46:54-60.

Khan, M. A., D. M. Weary, and M. A. G. von Keyserlingk. 2011. Invited review: Effects of milk ration on solid feed intake, weaning, and performance in dairy heifers. J. Dairy Sci. 94:1071-1081.
Kuller, W. I., T. J. Tobias, and A. van Nes. 2010. Creep feed intake in unweaned piglets is increased by exploration stimulating feeder. Livest. Prod. Sci. 129:228-231.

Launchbaugh, K. L., and L. D. Howery. 2005. Understanding landscape use patterns of livestock as a consequence of foraging behavior. Rangeland Ecol. Manag. 58:99-108.

Moallem, U., D. Werner, H. Lehrer, M. Zachut, L. Livshitz, S. Yakoby, and A. Shamay. 2010. Long-term effects of ad libitum whole milk prior to weaning and prepubertal protein supplementation on skeletal growth rate and first-lactation milk production. J. Dairy Sci. 93:2639-2650.

Phillips, C. J. C. 2004. The effects of forage provision and group size on the behavior of calves. J. Dairy Sci. 87:1380-1388.

Ralphs, M. H., D. Graham, and L. F. James. 1994. Social facilitation influences cattle to graze locoweed. J. Range Manage. 1994:123126.

Soberon, F., E. Raffrenato, R. W. Everett, and M. E. Van Amburgh. 2012. Preweaning milk replacer intake and effects on long-term productivity of dairy calves. J. Dairy Sci. 95:783-793.

Staněk, S., V. Zink, O. Doležal, and L. Stolc. 2014. Survey of preweaning dairy calf-rearing practices in Czech dairy herds. J. Dairy Sci. 97:3973-3981.

Tapki, İ. 2007. Effects of individual or combined housing systems on behavioural and growth responses of dairy calves. Acta Agric. Scand. A Anim. Sci. 57:55-60.

USDA. 2008. Dairy 2007, Part III: Reference of Dairy Cattle Health and Management Practices in the United States. 2007. USDA, National Animal Health Monitoring System, Fort Collins, CO.

Van Soest, P. J., J. B. Robertson, and B. A. Lewis. 1991. Methods for dietary fibre, neutral detergent fibre and non-starch polysaccharides in relation to animal nutrition. J. Dairy Sci. 74:3583-3597.

Vasseur, E., F. Borderas, R. I. Cue, D. Lefebvre, D. Pellerin, J. Rushen, K. M. Wade, and A. M. dePassillé. 2010. A survey of dairy calf management practices in Canada that affect animal welfare. J. Dairy Sci. 93:1307-1315.

Xiccato, G., A. Trocino, P. I. Queaque, A. Sartori, and A. Carazzolo. 2002. Rearing veal calves with respect to animal welfare: Effects of group housing and solid feed supplementation on growth performance and meat quality. Livest. Prod. Sci. 75:269-280. 